\title{
DETERMINATION OF OPTIMUM SOWING DATE AND PLANT POPULATION OF SOME SAFFLOWER CULTIVARS (Carthamus tinctorius L.) UNDER MOSUL CITY CONDITIONS
}

\author{
Saad A. M. Al-Doori \\ General Science Dept., College of Basic Education, Mosul University. Iraq \\ E-mail: saad35-ahmed@yahoo.com
}

\begin{abstract}
To determine the optimum sowing date and plant population for safflower crop (Carthamus tinctorius L.), a factorial experiment was conducted by using randomized completed block design with three replications in AL-Rashidia location about $(20 \mathrm{~km})$ west north Nineveh province, Iraq, during the 2008-2009 and 2009-2010 winter growing seasons. Three sowing dates $\left(1^{\text {st }}, 3^{\text {rd }}\right.$ October, $4^{\text {th }}, 5^{\text {th }}$ November and $2^{\text {nd }}, 1^{\text {st }}$ December for two seasons 2008-2009 and 2009-2010 respectively) and two plant populations (50000 and 100000 plants.ha $^{-1}$ ) were selected. Hartinan, Syrian and Gila cultivars were used. The results showed that the different sowing dates had significant effect on growth characters, yield, yield components and quality, except linoleic acid in 2009-2010 season, the highest mean values were obtained at second sowing date in the two seasons 2008-2009 and 2009-2010. Safflower cultivars significantly differed for all the studied yield, its component and seed quality traits in both seasons, the highest mean values were obtained from Syrian cultivar in both seasons. Seed yield and oil yield influenced by different plant population significantly. Plant population of 50000 plants.ha ${ }^{-1}$ gave the highest mean for seed oil content and oil yield, while increasing the plant population to 100000 plants.ha $^{-1}$ caused a significant increase of plant height and palmitic acid percentage in both growing seasons. The result of interaction among sowing dates, cultivars and plant population showed that the highest seed yield was obtained in Syrian cultivar sown in November using plant population of 50000 plants.ha ${ }^{-1}$. Therefore, Syrian cultivar sown in November with plant population of 50000 plants.ha $^{-1}$ is recommended for this region.
\end{abstract}

Keywords: Safflower cultivars, sowing dates, plant populations.

Received: 1/7/2012, Accepted: 6/5/2013.

\section{INTRODUCTION}

Safflower (Carthamus tinctorius L.) is an important annual industrial crop. The stem, leaves, seeds and flowers are used for different purposes. The orange-red dye (carthamin) extracted from it's brilliant colored flowers. Moreover, it's flowers are known to have many medicinal properties for curing several chronic diseases, and they are widely used in herbal preparations ( $\mathrm{Li}$ and Mundel, 1996). The leaves and shoots of safflower are used in salad. They are rich in vitamin A, iron, phosphorus, and calcium. Bundles of young plants are commonly sold as a green vegetable in markets (Nimbkar, 2002). Safflower can be grazed or stored as hay or silage. It's forage is palatable, and it's feed value and yields are similar to or better than those for oats or alfalfa. Thus, each part of safflower has a value attached to it. Safflower is an oil crop 
that can be grown in arid agricultural areas due to its high tolerance to heat and cold (Kaya et al., 2003; Zel et al., 2004; Dordas and Sioulas, 2008 and Moghanlou et al., 2011). Its seeds contain 13 to $46 \%$ oil, and approximately $90 \%$ of this oil is composed of unsaturated fatty acids, namely oleic and linoleic acids (Johnson et al., 1999). Safflower oil, contains approximately $75 \%$ linoleic acid, also contains tocopherol, which is have antioxidant effect and high vitamin E content. The yield and quality properties of safflower are largely determined by ecological factors and cultivation techniques. It was reported that the sowing date and plant population of safflower depend on ecological conditions (Alessi et al., 1981; Gencer et al., 1987; Rao et al., 1990; Pujari et al., 1993; Tomar, 1995; Patel et al., 1997; Samarthia and Muldoon, 1997). Gur and Ozel (1997) reported that the highest yield for safflower was obtained from November sowing of the cultivar Diner. Therefore, in order to obtain safflower with high yield and quality, it is essential to determine the suitable growth conditions and cultivation techniques. The aim of this study was to determine the optimum sowing date and plant population for safflower cultivars under semiarid conditions (193 mm rainfall) of Mosul City.

\section{MATERIALS AND METHODS}

Field trials were conducted in 2008-2009 and 2009-2010 winter growing seasons at AL-Rashidia location about $(20 \mathrm{~km})$ west north Nineveh province. Some climate data concerning the research area are given in table 1 (Anonymous, 2010). In 20082009 growing season, the total rainfall was much lower than the pattern of rainfall in 2009-2010 (see Table 1). According to soil analysis, the soil of the research area had an average levels of organic matter, $\mathrm{Caco}_{3}$ and $\mathrm{pH}$ of $0.905 \mathrm{mg} . \mathrm{kg}^{-1}, 2.03 \mathrm{mg} . \mathrm{kg}^{-1}$ and 7.81, respectively in both seasons (Table 2), and had a sandy loom texture using the methods described by Black, (1965); Jackson, (1973) and Page et al., (1982). Three sowing dates (October, November and December) and two plant population (50000 and 100000 plants.ha $^{-1}$ ) were applied. Hartinan, Syrian and Gila (with red flowers and unspiny) were used as the safflower cultivars and were supplied by the crops industrial company, Baghdad. Sowings were performed on $1^{\text {st }}, 3^{\text {rd }}$ October, $4^{\text {th }}, 5^{\text {th }}$ November and $2^{\text {nd }}, 1^{\text {st }}$ December for two seasons 2008-2009 and 2009-2010 respectively. Each plot $18 \mathrm{~m}^{2}(6 * 3)$, included six rows $50 \mathrm{~cm}$ apart and six meters long and the intra-row spacing was 40 and $20 \mathrm{~cm}$ to attain a plant population of 50000 and 100000 plant.ha ${ }^{-1}$, respectively.

The sowings were performed under rainfed only without supplemental irrigation. Plants were thinned after 20 days from sowing in both years. Nitrogen fertilizer was applied in the form of Urea $100 \mathrm{~kg} \cdot \mathrm{ha}^{-1}(46 \% \mathrm{~N})$ in two equal doses, after thinning immediately and 10 days later and super phosphate $60 \mathrm{~kg} \cdot \mathrm{ha}^{-1}\left(45 \% \mathrm{P}_{2} \mathrm{O}_{5}\right)$ and 40 $\mathrm{kg} \cdot \mathrm{ha}^{-1}$ potassium $\left(48 \% \mathrm{~K}_{2} \mathrm{O}\right)$ were applied to the soil during the sowing period. Plant protection practices were carried out when needed. Observations were carried out on 4 central rows, and $1 \mathrm{~m}$ from both ends of the rows was left as it represented the border effect, and the following data were recorded: Plant height $(\mathrm{cm})$, number of primary branches, number of head.plant ${ }^{-1}$ and head diameter. 
Table (1): The temperature, month precipitation and relative humidity in AL-Rashidia location at 2008-2009 and 2009-2010 seasons.

\begin{tabular}{|c|c|c|c|c|c|}
\hline \multicolumn{6}{|c|}{ 2008-2009 season } \\
\hline \multirow{2}{*}{ Month } & \multicolumn{3}{|c|}{ Temperature $\left(\mathrm{C}^{\circ}\right)$} & \multirow{2}{*}{$\begin{array}{c}\text { Month } \\
\text { Precipitation } \\
(\mathrm{mm})\end{array}$} & \multirow{2}{*}{$\begin{array}{l}\text { relative } \\
\text { humidity } \\
(\%)\end{array}$} \\
\hline & Max & Min & Mean & & \\
\hline September & 38.6 & 22.9 & 30.75 & 0.50 & 35 \\
\hline October & 30.4 & 15.6 & 23.00 & 34.20 & 48 \\
\hline November & 22.3 & 8.6 & 15.45 & 72.60 & 62 \\
\hline December & 15.0 & 3.2 & 9.10 & 18.60 & 71 \\
\hline January & 14.3 & -0.1 & 14.30 & 0.001 & 68 \\
\hline February & 17.5 & 5.6 & 11.55 & 24.90 & 63 \\
\hline March & 19.7 & 8.5 & 14.10 & 28.10 & 60 \\
\hline April & 25.8 & 11.7 & 18.75 & 35.70 & 52 \\
\hline May & 34.2 & 18.2 & 26.20 & 0.001 & 37 \\
\hline Total & & & & 214.60 & \\
\hline \multicolumn{6}{|c|}{ 2009-2010 season } \\
\hline September & 34.4 & 21.6 & 28 & 1.50 & 34 \\
\hline October & 32.3 & 15.0 & 23.65 & 24.00 & 43 \\
\hline November & 20.4 & 9.3 & 14.85 & 35.00 & 73 \\
\hline December & 16.0 & 7.0 & 11.5 & 75.00 & 81 \\
\hline January & 10.0 & 6.2 & 8.1 & 32.50 & 60.6 \\
\hline February & 15.8 & 8.8 & 12.3 & 61.50 & 58.2 \\
\hline March & 16.6 & 10.2 & 13.4 & 62.00 & 62.2 \\
\hline April & 24.6 & 22.8 & 23.7 & 14.50 & 58.0 \\
\hline May & 36.2 & 24.0 & 30.1 & 17.50 & 32.8 \\
\hline Total & & & & 323.50 & \\
\hline
\end{tabular}

Funding seismographic and meteorological commission, Mosul, Iraq.

Table (2): The physical and chemical characters of soil field experiments in both seasons at 0 to 30 depth.

\begin{tabular}{|c|c|c|c|}
\hline \multicolumn{2}{|c|}{ Seasons } & $2008-2009$ & $2009-2010$ \\
\hline \multicolumn{4}{|c|}{ physical characters } \\
\hline Sand & \multirow{3}{*}{$(\%)$} & 59.00 & 55.00 \\
\hline Silt & & 21.00 & 32.00 \\
\hline Clay & & 20.00 & 13.00 \\
\hline \multicolumn{2}{|c|}{ Texture } & Sandy loom & Sandy loom \\
\hline \multicolumn{4}{|c|}{ chemical characters } \\
\hline O.M. & \multirow{2}{*}{$\left(\mathrm{mg} \cdot \mathrm{kg}^{-1}\right)$} & 0.824 & 0.986 \\
\hline Total $\mathrm{CaCo}_{3}$ & & 1.64 & 2.42 \\
\hline Available $\mathrm{N}$ & \multirow{3}{*}{$(\mathrm{ppm})$} & 26.60 & 28.44 \\
\hline Available P & & 12.20 & 13.68 \\
\hline Available K & & 154.00 & 162.00 \\
\hline E.C. & $\left(\right.$ ds.cm $\left.{ }^{-1}\right)$ & 0.84 & 0.66 \\
\hline \multicolumn{2}{|c|}{$\mathrm{pH}$} & 7.20 & 8.42 \\
\hline
\end{tabular}


Harvesting was performed manually in 137, 132, 145 and 142, 141, 142 days after sowing for each cultivar Hartinan, Syrian and Gila to both seasons 2008-2009, 2009-2010, respectively. The two inner rows were taken to determine the following characters (No. of seeds.head ${ }^{-1}$ and 1000 seed weight). The final seed yield (ton per $\mathrm{ha}^{-1}$ ) was determined from the whole harvested plot area $\left(\mathrm{m}^{2}\right)$. Oil content was determined in $5 \mathrm{~g}$ by Soxhlet apparatus. Gas liquid chromatography was done for determining relative composition of different fatty acids in oil (Stoffel et al., 1995). Oil yield was calculated by multiplying oil content and the seed yield (Anonymous, 1980). The experimental design was factorial experiment in a Randomized Completely Block Design (RCBD) with three replications according to Snedecor and Cochran, (1982). Then Duncan's multiple range test (Duncan, 1955) was used to compare among means (Anonymous, 2001).

\section{RESULTS AND DISCUSSION}

Sowing dates effect: Temperature, rainfall and relative humidity for the experiment site during the study years are presented in table (1). The average rainfall for 2009$2010(323.50 \mathrm{~mm})$ was higher than that observed $(214.60 \mathrm{~mm})$ in $2008-2009$. Based on variance analysis table, all the investigated characteristics were affected by planting dates significantly at 0.05 and 0.01 probability level, except linoleic acid in 2009-2010 season (Table 5). Delaying in sowing date from October to November resulted in significant increase of plant height $(62.96,56.50 \mathrm{~cm})$, number of primary branches $(6.03,7.79)$, number of head.plant ${ }^{-1}(10.59,11.09)$, head diameter $(1.96,2.45 \mathrm{~cm})$, number of seed.head ${ }^{-1}(11.41,11.73)$, weight of 1000 seed $(29.29,27.73)$, seed yield $\left(1.62,1.64\right.$ ton.ha $\left.{ }^{-1}\right)$, oleic acid $(8.41,8.23 \%)$, palmitic acid $(6.87,9.73 \%)$ in the two seasons 2008-2009 and 2009-2010, respectively (Tables 3 and 4). Seed yield significantly decreased in October sowing date, as a result of the decrease in mean temperature during the period of vegetative growth of crop (Table 1). Growth conditions at October sowing date in comparison with December sowing date were not favorable because of very low temperature during seed filling stage and shrinkage of photoperiod. Seed yield obtained from the first and third planting dates decreased at the rate of $3.08,5.55 \%$ and $7.92,12.19 \%$ as compared with the second sowing date in the two seasons 2008-2009 and 2009-2010 respectively, mainly due to the optimum temperature during growth and seed formation stage in the second sowing date (Table 1). Safflower is a long day plant (Zimmerman, 1972) and it's flowering time is postponed in short day conditions. The physiological maturity of plant was delayed with declining mean temperature (Table 3). Similar results were reported by Cholaki et al., (1993); Tomar, (1995); Cazzato et al., (1997); Dadashi and Khajehpour, (2004) and Heydarizadeh et al., (2008).

Cultivars effect: Data pertaining to cultivars are presented in tables 3 and 4. All investigated characteristics were significantly affected by cultivars (Table 5). The data revealed that Syrian cultivar surpassed over Hartinan and Gila cultivars in the growth characters (plant height, number of primary branches, number of head.plant ${ }^{-1}$, head diameter). High number of heads per plant in Syrian cultivar indicated that this cultivar had the most adaptability to the climatic conditions of the region. On the other hand, the high number of seeds per head in Syrian cultivar may be attributed to large head formation in this cultivar (Table 3). Moreover producing the heaviest seeds by Syrian 
was probably as the result of desirable transportation of photosynthesis products to seeds of this cultivar. Superiority of Syrian cultivar over Hartinan and Gila with respect to seed yield, oil yield, oleic and palmitic acid percentage in this study suggested that Syrian was the most compatible cultivar for cultivation in the region. Variations among different cultivars regarding productivity and yield have been shown by other authors (Gonzalez et al., 1994; Camas et al., 2007; Koutroubas et al., 2009 and Beyyavas et al., 2011). These results about yield components responses to cultivar factor are very similar to the findings of Gonzalez et al., (1994); Arslan et al., (1997) and Dadashi and Khajehpour, (2004).

Plant populations effect: Increasing the plant population from 50000 to 100000 plants.ha ${ }^{-1}$ resulted in decreasing the all investigated characteristics except plant height and palmitic acid percentage (Tables 3 and 4). Although the high population (100000 plants.ha $\left.{ }^{-1}\right)$ produced the highest plant height $(63.00,55.73 \mathrm{~cm})$ and palmitic acid $(6.84,9.37 \%)$, the low population (50000 plant.ha. $\left.^{-1}\right)$ gave the highest number of primary branches $(5.46,7.08)$, seed oil percentage $(29.13,29.16 \%)$, oil yield $(0.46$, 0.46 ton. $^{-1} \mathrm{a}^{-1}$ ) in the two growing seasons, respectively. The consequent increase in seed yield per $\mathrm{ha}^{-1}$ by decreasing the plant population from 100000 to 50000 plants.ha ${ }^{1}$ may be attributed to increases in head diameter and number of head per plant ${ }^{-1}$ as a result of decreased plant competition. This is in agreement with those reported by Alessi et al., (1981) and Fazeli Kakhaki et al., (2007).

Oil yield also, was lower in the plant population of 100000 plants per ha ${ }^{-1}$ than the population of 50000 plants perha ${ }^{-1}$. It seems that the ratio of growth enhancement in vegetative parts of plant (height) was more evident than reproductive organs, due to increasing of plant population. This increase may be due to the decreased plant competition for resources in low plant population. These results were in agreement with the findings of Mundel et al., (1994). On the other hand, the reduction of heads number per plant, decreased branching in the plants, and the acceleration of plant height in higher plant population can be ascribed to inter and intra plant competition for resources. These results were in agreement with the findings of Azari and Khajehpour, (2005).

Interactions effect: Tables (3 and 4 ) showed that the interaction between sowing dates and cultivars had a significant effect on plant height and no. of seed.head ${ }^{-1}$ in 2009-2010 season, head diameter, 1000 seed weight, seed yield, seed oil percentage, oil yield, oleic, linoleic and palmitic acid percentage for both seasons. It seems that the late planting date at November produce more vegetative branches due to longer vegetative period. Similar conclusions were obtained by Jose et al., (2004). The interaction between sowing dates $\times$ plant population showed significant effects on plant height and linoleic acid percentage in 2008-2009 season, as well as number of seed per head ${ }^{-1}$, oil yield and oleic acid percentage in 2009-2010 season, while number of head.plant ${ }^{-1}$, weight of 1000 seed, seed yield, seed oil content significantly increased in both seasons as illustrated in tables 3 and 4. The increase in number of heads per plant and weight of 1000 seed in November planting date and 50000 plants per ha ${ }^{-1}$ may be due to the favorable climate conditions and low plant competition that lead to enough plant nourishment, so the yield component increased and total seed yield. These results are in agreement with those obtained by Ozel et al., (2004). 
Table (3): Mean values of plant height, no. of primary branches. plant ${ }^{-1}$, no. of head. plant ${ }^{-1}$, head diameter (cm), no. of seed.head ${ }^{-1}$ and 1000 seed weight as affected by sowing dates and plant population for the safflower cultivars in 2008-2009 and 2009-2010 seasons.

\begin{tabular}{|c|c|c|c|c|c|c|c|c|c|c|c|c|}
\hline \multirow{2}{*}{$\begin{array}{c}\text { Main } \\
\text { effect and } \\
\text { interaction }\end{array}$} & \multicolumn{2}{|c|}{ plant height $(\mathrm{cm})$} & \multicolumn{2}{|c|}{$\begin{array}{c}\text { no. of primary } \\
\text { branches. plant }{ }^{-1}\end{array}$} & \multicolumn{2}{|c|}{ no. of head.plant ${ }^{-1}$} & \multicolumn{2}{|c|}{$\begin{array}{l}\text { head diameter } \\
(\mathrm{cm})\end{array}$} & \multicolumn{2}{|c|}{ no. of seed.head } & \multicolumn{2}{|c|}{$\begin{array}{l}\text { weight of } 1000 \\
\text { seed }(\mathrm{g})\end{array}$} \\
\hline & $\begin{array}{c}2008- \\
2009 \\
\end{array}$ & $\begin{array}{c}2009- \\
2010 \\
\end{array}$ & $\begin{array}{l}2008- \\
2009 \\
\end{array}$ & $\begin{array}{c}2009- \\
2010 \\
\end{array}$ & $\begin{array}{l}2008- \\
2009 \\
\end{array}$ & $\begin{array}{c}2009- \\
2010 \\
\end{array}$ & $\begin{array}{c}2008- \\
2009 \\
\end{array}$ & $\begin{array}{c}2009- \\
2010 \\
\end{array}$ & $\begin{array}{c}2008- \\
2009 \\
\end{array}$ & $\begin{array}{c}2009- \\
2010 \\
\end{array}$ & $\begin{array}{c}2008- \\
2009 \\
\end{array}$ & $\begin{array}{c}2009- \\
2010\end{array}$ \\
\hline \multicolumn{13}{|c|}{ Sowing dates } \\
\hline October & $59.25 b$ & $51.76 b$ & $4.56 \mathrm{~b}$ & $5.98 b$ & $10.48 \mathrm{a}$ & $10.79 \mathrm{a}$ & $1.74 \mathrm{~b}$ & $1.99 \mathrm{~b}$ & $11.12 \mathrm{a}$ & $11.00 \mathrm{~b}$ & $26.90 \mathrm{~b}$ & $24.78 b$ \\
\hline November & $62.96 a$ & $56.50 \mathrm{a}$ & $6.03 a$ & $7.79 a$ & $10.59 \mathrm{a}$ & $11.09 \mathrm{a}$ & $1.96 \mathrm{a}$ & $2.45 \mathrm{a}$ & $11.41 \mathrm{a}$ & $11.73 \mathrm{a}$ & $29.29 a$ & $27.73 a$ \\
\hline December & $55.58 \mathrm{c}$ & $48.42 b$ & $4.84 b$ & $6.28 b$ & $9.31 b$ & $9.52 \mathrm{~b}$ & $1.50 \mathrm{c}$ & $1.78 \mathrm{~b}$ & $10.01 \mathrm{~b}$ & $9.88 \mathrm{c}$ & $25.83 c$ & $23.71 \mathrm{c}$ \\
\hline \multicolumn{13}{|c|}{ cultivars } \\
\hline Hartinan & $54.41 \mathrm{c}$ & $47.25 \mathrm{c}$ & $4.61 b$ & $6.02 b$ & $8.59 \mathrm{c}$ & $8.79 \mathrm{c}$ & $1.45 \mathrm{~b}$ & $1.70 \mathrm{~b}$ & $10.37 b$ & $10.25 b$ & $26.56 b$ & $24.44 b$ \\
\hline Syrian & $63.85 \mathrm{a}$ & $57.06 \mathrm{a}$ & $5.83 a$ & $7.60 \mathrm{a}$ & $11.66 a$ & $12.27 \mathrm{a}$ & $1.89 \mathrm{a}$ & $2.38 \mathrm{a}$ & $11.29 \mathrm{a}$ & $11.61 \mathrm{a}$ & $28.17 \mathrm{a}$ & $26.61 \mathrm{a}$ \\
\hline Gila & $59.53 b$ & $52.37 \mathrm{~b}$ & $4.99 \mathrm{~b}$ & $6.43 b$ & $10.13 b$ & $10.34 b$ & $1.86 a$ & $2.14 \mathrm{a}$ & $10.87 \mathrm{ab}$ & $10.75 b$ & $27.29 b$ & $25.17 \mathrm{~b}$ \\
\hline \multicolumn{13}{|c|}{ Plant population (plants.ha ${ }^{-1}$ ) } \\
\hline 50000 & $55.53 b$ & $48.73 b$ & $5.46 \mathrm{a}$ & $7.08 \mathrm{a}$ & 10.37 & 10.83 & 1.77 & 2.18 & 10.93 & 11.07 & 27.54 & 25.74 \\
\hline 100000 & $63.00 \mathrm{a}$ & $55.73 \mathrm{a}$ & $4.82 b$ & $6.29 b$ & 9.88 & 10.11 & 1.69 & 1.97 & 10.76 & 10.68 & 27.14 & 25.08 \\
\hline \multicolumn{13}{|c|}{ Interactions } \\
\hline $\mathrm{S} \times \mathrm{C}$ & N.S. & $* *$ & N.S. & N.S. & N.S. & N.S. & $* *$ & $* *$ & N.S. & $* *$ & $* *$ & $* *$ \\
\hline $\mathrm{S} \times \mathrm{P}$ & $* *$ & N.S. & N.S. & N.S. & $*$ & $* *$ & N.S. & N.S. & N.S. & $*$ & $* *$ & $* *$ \\
\hline $\mathrm{C} \times \mathrm{P}$ & $* *$ & $* *$ & N.S. & $* *$ & N.S. & N.S. & $* *$ & $* *$ & N.S. & $* *$ & N.S. & $*$ \\
\hline $\begin{array}{c}\mathrm{S} \times \mathrm{C} \times \\
\mathrm{P}\end{array}$ & $* *$ & $* *$ & $*$ & $* *$ & N.S. & $*$ & $*$ & $*$ & N.S. & $*$ & $* *$ & $* *$ \\
\hline
\end{tabular}

The mean values with in column followed by different letters are significantly at 0.05 and 0.01 level.

${ }^{*},{ }^{* *}$ significant at the 0.05 and 0.01 probability level, respectively.

N.S. not significant. 
Table (4): Mean values of seed yield, seed oil percentage, oil yield, oleic, linoleic and palmitic acid percentage as affected by sowing dates and plant population for the safflower cultivars in 2008-2009 and 2009-2010 seasons.

\begin{tabular}{|c|c|c|c|c|c|c|c|c|c|c|c|c|}
\hline \multirow{2}{*}{$\begin{array}{c}\text { Main } \\
\text { effect and } \\
\text { interaction }\end{array}$} & \multicolumn{2}{|c|}{ seed yield (ton.ha ${ }^{-1}$ ) } & \multicolumn{2}{|c|}{ seed oil $(\%)$} & \multicolumn{2}{|c|}{ oil yield (ton.ha ${ }^{-1}$ ) } & \multicolumn{2}{|c|}{ oleic acid (\%) } & \multicolumn{2}{|c|}{ linoleic acid $(\%)$} & \multicolumn{2}{|c|}{ palmitic acid $(\%)$} \\
\hline & $\begin{array}{l}2008- \\
2009\end{array}$ & $\begin{array}{l}2009- \\
2010\end{array}$ & $\begin{array}{l}2008- \\
2009\end{array}$ & $\begin{array}{c}2009- \\
2010\end{array}$ & $\begin{array}{l}2008- \\
2009\end{array}$ & $\begin{array}{l}2009- \\
2010\end{array}$ & $\begin{array}{l}2008- \\
2009\end{array}$ & $\begin{array}{l}2009- \\
2010\end{array}$ & $\begin{array}{c}2008- \\
2009\end{array}$ & $\begin{array}{l}2009- \\
2010\end{array}$ & $\begin{array}{c}2008- \\
2009\end{array}$ & $\begin{array}{l}2009- \\
2010\end{array}$ \\
\hline \multicolumn{13}{|c|}{ Sowing dates } \\
\hline October & $1.57 \mathrm{~b}$ & $1.51 \mathrm{~b}$ & $27.56 \mathrm{~b}$ & $27.34 \mathrm{~b}$ & $0.43 b$ & $0.41 \mathrm{~b}$ & $8.12 \mathrm{a}$ & $7.44 \mathrm{~b}$ & $70.21 b$ & 66.51 & $6.53 \mathrm{a}$ & $8.84 b$ \\
\hline November & $1.62 \mathrm{a}$ & $1.64 \mathrm{a}$ & $29.09 a$ & $29.32 \mathrm{a}$ & $0.47 \mathrm{a}$ & $0.48 \mathrm{a}$ & $8.41 \mathrm{a}$ & $8.23 a$ & $72.55 \mathrm{a}$ & 65.80 & $6.87 a$ & $9.73 a$ \\
\hline December & $1.53 \mathrm{c}$ & $1.44 \mathrm{~b}$ & $27.93 b$ & $27.66 \mathrm{~b}$ & $0.42 b$ & $0.40 \mathrm{~b}$ & $7.01 \mathrm{~b}$ & $6.41 \mathrm{c}$ & $70.88 b$ & 66.80 & $5.64 \mathrm{~b}$ & $8.20 \mathrm{~b}$ \\
\hline \multicolumn{13}{|c|}{ cultivars } \\
\hline Hartinan & $1.45 \mathrm{c}$ & $1.39 \mathrm{~b}$ & $26.15 \mathrm{c}$ & $25.93 c$ & $0.37 \mathrm{~b}$ & $0.36 \mathrm{c}$ & $7.37 \mathrm{~b}$ & $6.70 \mathrm{c}$ & $69.68 c$ & $65.99 \mathrm{~b}$ & $5.75 b$ & $8.06 \mathrm{~b}$ \\
\hline Syrian & $1.74 \mathrm{a}$ & $1.76 \mathrm{a}$ & $27.64 b$ & $27.87 \mathrm{~b}$ & $0.48 \mathrm{a}$ & $0.49 \mathrm{a}$ & $8.29 a$ & $8.12 \mathrm{a}$ & $71.30 \mathrm{~b}$ & $64.55 c$ & $6.78 \mathrm{a}$ & $9.65 \mathrm{a}$ \\
\hline Gila & $1.53 \mathrm{~b}$ & $1.44 \mathrm{~b}$ & $30.80 \mathrm{a}$ & $30.53 a$ & $0.47 \mathrm{a}$ & $0.44 b$ & $7.87 \mathrm{ab}$ & $7.28 \mathrm{~b}$ & $72.66 \mathrm{a}$ & $68.58 \mathrm{a}$ & $6.50 \mathrm{ab}$ & $9.06 a$ \\
\hline \multicolumn{13}{|c|}{ Plant population (plants.ha ${ }^{-1}$ ) } \\
\hline 50000 & 1.58 & $1.58 \mathrm{a}$ & $29.13 \mathrm{a}$ & $29.16 \mathrm{a}$ & $0.46 \mathrm{a}$ & $0.46 \mathrm{a}$ & 7.93 & 7.55 & $72.87 \mathrm{a}$ & $67.19 \mathrm{a}$ & $5.85 \mathrm{~b}$ & $8.48 b$ \\
\hline 100000 & 1.57 & $1.49 \mathrm{~b}$ & $27.26 \mathrm{~b}$ & $27.06 \mathrm{~b}$ & $0.42 b$ & $0.40 \mathrm{~b}$ & 7.76 & 7.17 & $69.56 \mathrm{~b}$ & $65.55 b$ & $6.84 \mathrm{a}$ & $9.37 \mathrm{a}$ \\
\hline \multicolumn{13}{|c|}{ Interactions } \\
\hline $\mathrm{S} \times \mathrm{C}$ & $* *$ & $* *$ & $* *$ & $* *$ & $* *$ & $* *$ & $*$ & $* *$ & $* *$ & $* *$ & $*$ & $* *$ \\
\hline $\mathrm{S} \times \mathrm{P}$ & $* *$ & $* *$ & $*$ & $*$ & N.S. & $* *$ & N.S. & $* *$ & $* *$ & N.S. & N.S. & N.S. \\
\hline $\mathrm{C} \times \mathrm{P}$ & N.S. & N.S. & N.S. & N.S. & N.S. & N.S. & N.S. & $* *$ & N.S. & $* *$ & N.S. & N.S. \\
\hline $\begin{array}{c}\mathrm{S} \times \mathrm{C} \times \\
\mathrm{P}\end{array}$ & $* *$ & $* *$ & N.S. & N.S. & N.S. & $* *$ & N.S. & $* *$ & N.S. & $* *$ & $* *$ & $* *$ \\
\hline
\end{tabular}

The mean values with in column followed by different letters are significantly at 0.05 and 0.01 level.

*,** significant at the 0.05 and 0.01 probability level, respectively.

N.S. not significant. 
Mesopotamia J. of Agric.

Vol. (45) No. (2) 2017
ISSN: 2224 - 9796 (Online) ISSN: 1815 - 316 X (Print)
مـجلـــة زراعـــة الـر افديـنـ المجلد (45) العدد (2) 2017

Table (5): Analysis of variance F values for some growth characters, yield and yield components and quality in 2008-2009 and 2009-2010 seasons.

\begin{tabular}{|c|c|c|c|c|c|c|c|c|c|c|c|c|c|}
\hline \multirow[b]{2}{*}{ S.O.V } & \multirow[b]{2}{*}{ D.f } & \multicolumn{12}{|c|}{ M.S. for 2008-2009 season } \\
\hline & & $\begin{array}{l}\text { plant } \\
\text { height } \\
(\mathrm{cm})\end{array}$ & $\begin{array}{c}\text { no. of } \\
\text { primary } \\
\text { branches. } \\
\text { plant }^{-1}\end{array}$ & $\begin{array}{c}\text { no. of } \\
\text { head.plant }^{-1}\end{array}$ & $\begin{array}{c}\text { head } \\
\text { diameter } \\
(\mathrm{cm})\end{array}$ & $\begin{array}{c}\text { no. of } \\
\text { seed.head }^{-1}\end{array}$ & $\begin{array}{c}\text { weight of } \\
1000 \\
\text { seed }(\mathrm{g})\end{array}$ & $\begin{array}{c}\text { seed } \\
\text { yield } \\
\left(\text { ton.ha }^{-1}\right)\end{array}$ & $\begin{array}{l}\text { seed oil } \\
(\%)\end{array}$ & $\begin{array}{l}\text { oil yield } \\
\text { (ton.ha }^{-1} \text { ) }\end{array}$ & $\begin{array}{l}\text { oleic acid } \\
(\%)\end{array}$ & $\begin{array}{l}\text { linoleic } \\
\text { acid }(\%)\end{array}$ & $\begin{array}{l}\text { palmitic } \\
\text { acid }(\%)\end{array}$ \\
\hline Replications & 2 & 126.157 & 3.3523 & 2.56193 & 0.0113 & 4.1905 & 1.0007 & 0.0065 & 0.7318 & 0.0002 & 4.3438 & 4.3634 & 1.4074 \\
\hline A & 2 & $244.943^{* *}$ & $10.8666^{* *}$ & $9.04007^{*}$ & $0.9296^{* *}$ & $9.8900^{* * *}$ & $56.655^{* * *}$ & $0.0351^{* *}$ & $11.494^{*}$ & $0.0101^{* *}$ & $9.8900^{* *}$ & $26.217^{* * *}$ & $7.2130^{* *}$ \\
\hline $\mathrm{B}$ & 2 & $402.348^{* *}$ & $7.0327^{* *}$ & $42.3667^{* * *}$ & $1.0931^{* *}$ & $3.8150^{*}$ & $11.763^{\text {** }}$ & $0.4020^{* *}$ & $101.447^{* *}$ & $0.0580^{* *}$ & $3.8150^{*}$ & $40.018^{* *}$ & $5.1347^{*}$ \\
\hline $\mathrm{C}$ & 1 & $754.13^{* *}$ & $5.4403^{* *}$ & $3.2462^{\text {N.S. }}$ & $0.0816^{\text {N.S. }}$ & $0.3833^{\text {N.S. }}$ & $2.1600^{\text {N.S. }}$ & $0.0024^{\text {N.S. }}$ & $47.601^{* *}$ & $0.0148^{* * *}$ & $0.3833^{* * *}$ & $147.47^{* *}$ & $13.093^{*}$ \\
\hline$A \times B$ & 4 & $130.39^{\text {N.S. }}$ & $0.411^{\text {N.S. }}$ & $4.7083^{\text {N.S. }}$ & $0.4784^{* *}$ & $1.8632^{\text {N.S. }}$ & $19.760^{* *}$ & $0.0251^{* *}$ & $20.944^{* *}$ & $0.0088^{*}$ & $1.8632^{* *}$ & $68.449^{* * *}$ & $3.9149^{* *}$ \\
\hline$A \times C$ & 2 & $4.9312^{* *}$ & $0.502^{\text {N.S. }}$ & $7.93127^{*}$ & $0.1784^{\text {N.S. }}$ & $1.1849^{\text {N.S. }}$ & $18.346^{* * *}$ & $0.0432^{* *}$ & $11.473^{* *}$ & $0.0009^{\text {N.S. }}$ & $1.1849^{\text {N.S. }}$ & $17.141^{* * *}$ & $2.7299^{\text {N.S. }}$ \\
\hline $\mathrm{B} \times \mathrm{C}$ & 2 & $344.509^{* *}$ & $1.640^{\text {N.S. }}$ & $2.0022^{\text {N.S. }}$ & $0.6776^{* *}$ & $1.5038^{\text {N.S. }}$ & $3.5332^{\text {N.S. }}$ & $0.0037^{\text {N.S. }}$ & $4.2355^{\text {N.S. }}$ & $0.0001^{\text {N.S. }}$ & $1.5038^{\text {N.S. }}$ & $4.4565^{\text {N.S. }}$ & $0.7136^{\text {N.S. }}$ \\
\hline $\mathrm{A} B \times \mathrm{C}$ & 4 & $245.032^{* *}$ & $2.1768^{*}$ & $3.1238^{\text {N.S. }}$ & $0.2313^{*}$ & $0.7202^{\text {N.S. }}$ & $38.740^{* *}$ & $0.0265^{* *}$ & $1.0104^{\text {N.S. }}$ & $0.0014^{\text {N.S. }}$ & $0.7202^{\text {N.S. }}$ & $4.4706^{\text {N.S. }}$ & $6.2114^{* *}$ \\
\hline Error & 34 & 26.29447 & 0.572135 & 2.046903 & 0.09047 & 0.743332 & 1.526230 & 0.003310 & 2.691459 & 0.000753 & 0.734312 & 2.072011 & 1.289760 \\
\hline Total & 53 & & & & & & & & & & & & \\
\hline Replications & 2 & 15.05722 & 1.337362 & 155.38040 & 3.597016 & 120.6307 & 167.4401 & 1.306903 & 68.19334 & 0.192789 & 71.96072 & 27.35778 & 16.70456 \\
\hline $\mathrm{A}$ & 2 & $296.567^{* *}$ & $16.9587^{* *}$ & $12.5315^{* *}$ & $2.11802^{* *}$ & $15.5907^{* *}$ & $78.0422^{* *}$ & $0.18450^{* *}$ & $20.2835^{* *}$ & $0.03630^{* *}$ & $15.0977^{* *}$ & $4.7232^{\text {N.S. }}$ & $10.7092^{* *}$ \\
\hline B & 2 & $433.442^{* * *}$ & $11.9681^{* *}$ & $54.5140^{* * *}$ & $2.13060^{* * *}$ & $8.56466^{* * *}$ & $21.9391^{* * *}$ & $0.73782^{* *}$ & $95.7507^{* *}$ & $0.08409^{* *}$ & $9.16766^{* *}$ & $74.9364^{* * *}$ & $11.6032^{* * *}$ \\
\hline $\mathrm{C}$ & 1 & $662.900^{* *}$ & $8.51247^{* *}$ & $6.9265^{\text {N.S. }}$ & $0.5601^{\text {N.S. }}$ & $2.0611^{\text {N.S. }}$ & $5.8674^{\text {N.S. }}$ & $0.1084^{\text {N.S. }}$ & $59.5350^{* *}$ & $0.04764^{* *}$ & $1.9078^{\text {N.S. }}$ & $36.2440^{* * *}$ & $10.6577^{* * *}$ \\
\hline $\mathrm{A} \times \mathrm{B}$ & 4 & $164.720^{* *}$ & $1.0947^{\text {N.S. }}$ & $4.5305^{\text {N.S. }}$ & $1.17944^{* *}$ & $4.44230^{* *}$ & $26.6476^{* *}$ & $0.12996^{* *}$ & $25.0921^{* *}$ & $0.02083^{* *}$ & $5.08269^{* *}$ & $105.286^{* * *}$ & $7.96376^{* * *}$ \\
\hline $\mathrm{A} \times \mathrm{C}$ & 2 & $17.019^{\text {N.S. }}$ & $1.1698^{\text {N.S. }}$ & $13.6891^{* *}$ & $0.5836^{\text {N.S. }}$ & $3.03162^{*}$ & $20.6536^{* *}$ & $0.13114^{* *}$ & $16.0542^{*}$ & $0.01108^{* *}$ & $3.95217^{* *}$ & $11.675^{\text {N.S. }}$ & $2.8652^{\text {N.S. }}$ \\
\hline $\mathrm{B} \times \mathrm{C}$ & 2 & $350.987^{* *}$ & $4.11419^{* * *}$ & $4.8069^{\text {N.S. }}$ & $1.78746^{* *}$ & $4.58159^{* *}$ & $9.30397^{*}$ & $0.0320^{\text {N.S. }}$ & $1.5444^{\text {N.S. }}$ & $0.0040^{\text {N.S. }}$ & $5.36259^{* *}$ & $72.0870^{* * *}$ & $0.7687^{\text {N.S. }}$ \\
\hline $\mathrm{A} \mathrm{B} \times \mathrm{C}$ & 4 & $216.788^{* *}$ & $4.11911^{* *}$ & $6.303279^{*}$ & $0.87151^{*}$ & $2.84862^{*}$ & $49.8158^{* *}$ & $0.15849^{* *}$ & $0.5990^{\text {N.S. }}$ & $0.01561^{* *}$ & $2.90201^{* *}$ & $55.6259^{* * *}$ & $6.52740^{* * *}$ \\
\hline Error & 34 & 30.50055 & 0.684664 & 2.165739 & 0.27136 & 0.810608 & 2.015555 & 0.011556 & 3.162701 & 0.001950 & 0.678308 & 3.926979 & 1.424531 \\
\hline Total & 53 & & & & & & & & & & & & \\
\hline
\end{tabular}

*** Significant at the 0.05 and 0.01 probability level, respectively. and n.s. not significant. 
According to the results of mean comparisons (Tables 3 and 4) interaction of safflower cultivars $\times$ plant population showed significant effects on number of primary branches, number of seed.head ${ }^{-1}$, weight of 1000 seed, oleic and linoleic acid percentage in 2009-2010 season, while plant height, head diameter significantly increased in both seasons as illustrated in tables 3 and 4. Similar results were found by Cazzato et al., (1997). As it is shown in variance analysis table, plant height, number of primary branches, head diameter, weight of 1000 seed, seed yield and palmitic acid percentage influenced by interaction among sowing dates $\times$ cultivars $\times$ plant population significantly at 0.05 and 0.01 probability level (Table 5) at two seasons. Syrian cultivar in November planting date and low plant density surpassed over Hartinan and Gila cultivars in total seed yield and oil yield. November planting date is suitable for vegetative growth and organ reproductive, the environmental temperature is consistent with optimal condition for biological performance and dry matter accumulation improvement. The insignificant effect among the three studying factors on other characteristic showed that each of these three factors acted independently on these traits.

According to the results of present study, and in order to cultivate safflower in conditions similar to the region of this experiment, it recommended that safflower should be sown at November. Delaying of safflower planting to December will cause a decrease in yield and oil yield due to day length shortage consequently the reproductive phase of crop development and seed filling stage may coincide with low temperatures leading to expressing drop in crop yield and productivity. The relatively high yielding of Syrian cultivar with more compatibility than other two cultivars is suggested for cultivation at November in the region with a plant population of about 50000 plants.ha $^{-1}$.

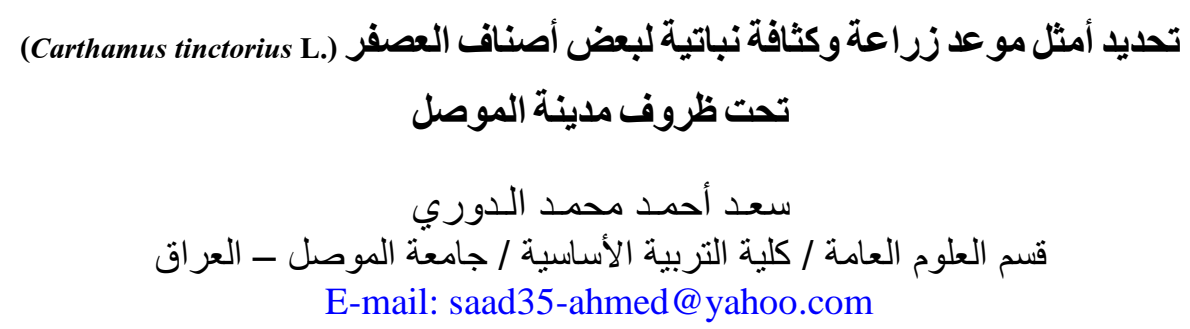

\section{الخلاصة}

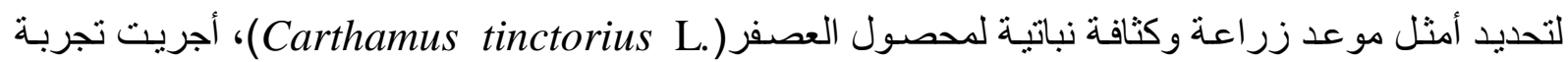

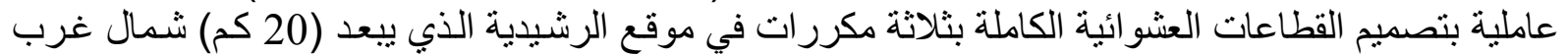

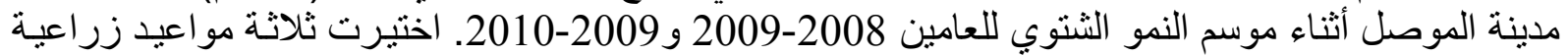

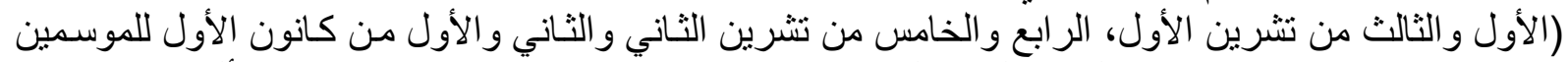

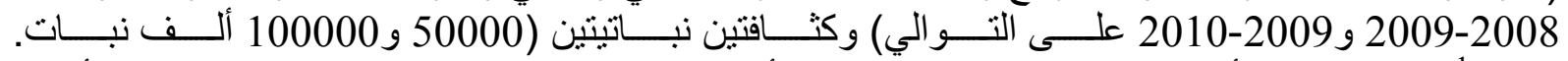

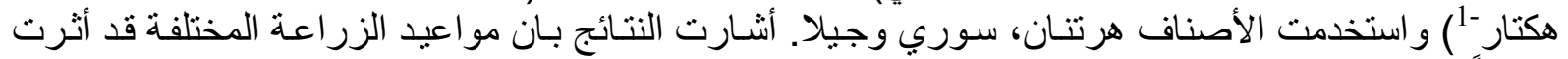

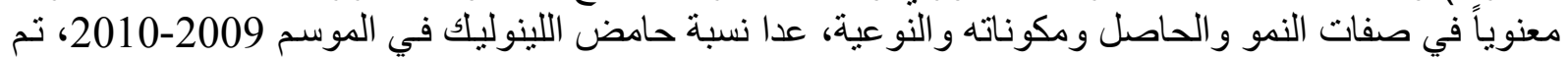

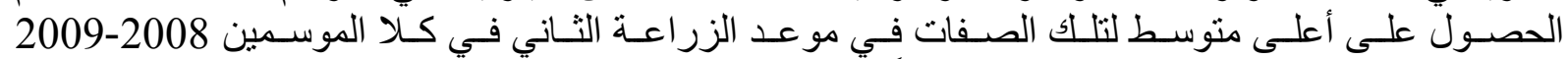

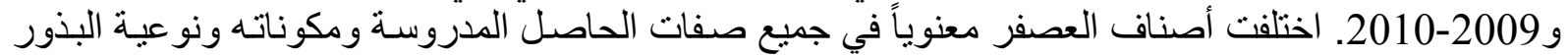

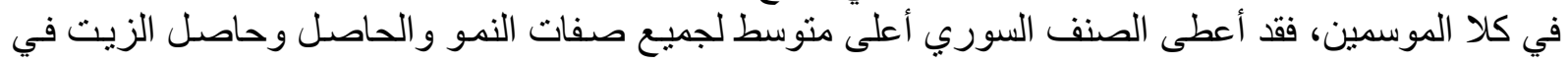


كلا الموسمين 2008-2009 و2009-2010. تـأثز حاصـلي البـذور والزيت معنويـاً بـاختلاف الكثافـة النباتيـة.

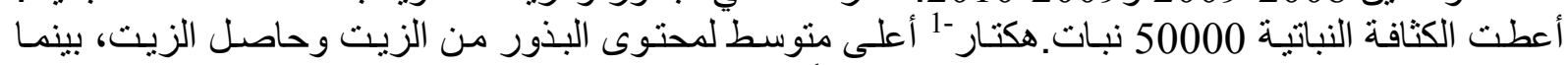

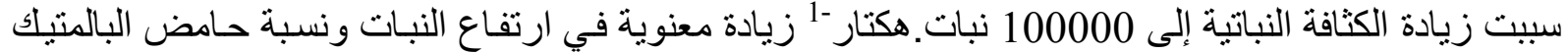

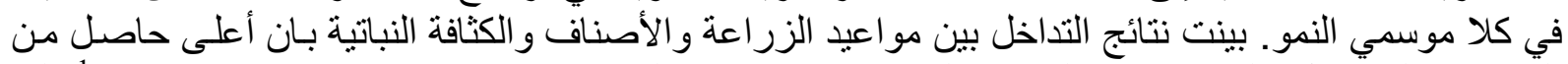

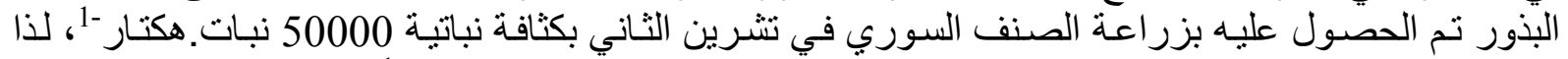
يوصى بزر اعة الصنف السوري في تشرين الثاني بكثافة نباتية

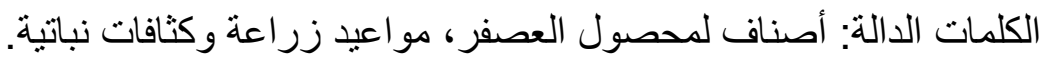
تاريخ تسلم البحث: 2012/7/1 ، وقبوله: 2013/5/6.

\section{REFERENCES}

Alessi, J.; J.F., Power and D.C., Zimmerman (1981). Effects of seeding date and population on water use efficiency and Safflower yield. Agronomy Journal, 73: 783-787.

Anonymous, (1980). Official Methods Of Analysis. $14^{\text {th }}$ Edition Association Of Official Analytical Chemists Washington, D.C, USA.

Anonymous, (2001). Statistics Analysis System User's Guide: Statistics. SAS Inst., Cary, NC. USA.

Anonymous, (2010). Funding Seismographic and Meteorological Commission, Mosul, Iraq.

Arslan, B.; B. Yildirim; A. I. Ilbas, O. Dede and N. Okut (1997). The effect of sowing date on yield and yield characters of varieties of Safflower (Carthamus tinctorius L.). pp.125-131. Paper Presented At The Fourth International Safflower Conference. Bari, Italy.

Azari, A. and M. R. Khajehpour (2005). Effect of planting pattern on development, growth, yield components and seed and petal yields of Safflower in summer planting, local variety of Isfahan, Koseh. Journal of Science and Technology of Agriculture and Natural Resources, 9 (3):131-142.

Beyyavas, V.; H., Haliloglu; O., Copur and A., Yilmaz (2011). Determination of seed yield and yield components of some Safflower cultivars, lines and populations under the semi-arid conditions. African Journal of Biotechnology, 10(4): 527 534.

Black, C. A. (1965). Methods Of Soil Analysis. Part 2. Chemical and Microbiological Properties. Amer. Soc. of Agronomy. Inc. Publisher Madison. USA.

Camas, N.; C., Cirak and E., Esendal (2007). Seed yield, oil content and fatty acids composition of Safflower grown in northern Turkey conditions. Journal of Facility of Agriculture. OMU, 22(1): 98-104.

Cazzato, E.; P.,Ventricelli and A., Corleto (1997). Effects of date of seeding and supplemental irrigation on hybrid and open-pollinated Safflower production in southern Italy. pp. 119- 124. Paper Presented At The Fourth International Safflower Conference, Bari, Italy.

Cholaki, L.; E. M., Fernandez; W.E., Asnal; O., Giayetto and Y. J. O., Plevich (1993). Safflower (Carthamus tinctorius L.) sowing dates in Rio Cuouto. pp: 395-402. 
Paper Presented At The Third International Safflower Conference, Beijing, China. June 14-18.

Dadashi, N. and M. R., Khajehpour (2004). Effects of planting date and cultivar on growth, yield components and seed yield of Safflower in Isfahan. Journal of Science and Technology of Agriculture and Natural Resources, 8(3): 95-112.

Dordas, C. A. and C., Sioulas (2008). Safflower yield, chlorophyll content, photosynthesis and water use efficiency response to nitrogen fertilization under rainfed conditions. Journal of Indian Crops Production, 27(1):75-85.

Duncan, B. O. (1955). Multiple range and multiple F test. Biometrics 11:1-42.

Fazeli Kakhaki, S. F.; R. Sadrabadi Haghighi; A. Zare Feyzabadi and M. Ezzat Ahmadi (2007). The effect of sowing date and plant population on yield and yield components of Safflower in Rokh plateau. Journal Of Iranian Field Crop Research, 5(2): 327-332.

Gencer, O.; N. S. Sinan and F. G., Lyasar (1987). Cukuovaoda sulanmayan alanlarda yetistirilebilecek aspirde uygun sira araliginin saptanmasi uzerinde bir arastirma. Ukurova Universitesi Ziraat Fakultesi Dergisi, 2: 54-68.

Gonzalez, J. L.; A. A., Schneiter; N. R., Riveland and B. L., Johnson (1994). Response of hybrid and open-pollinated Safflower to plant population. Agronomy Journal, 86:1070-1073.

Gur, M. A. and A., Ozel (1997). Harran Ovasi kosullarinda aspired farkliekim zamanlarinin verim ve verim unsurlarina etkisi. Harran Universitesi Ziraat Fak. ltesi Dergisi, 1: 77-84.

Heydarizadeh, P.; M. Sabzalian and M. R., Khajehpour (2008). Effect of temperature and day length on vegetative growth and yield of Safflower genotypes. Journal of Science and Technology of Agriculture and Natural Resources, 12(45): 365 376.

Jackson, M. L. (1973). Soil Chemical Analysis. Prentice Hall of India Pvt., New Delhi.

Johnson, R. C.; J. W., Bergman and C. R., Flynn (1999). Oil and meal characteristics of core and non-core Safflower accessions from the usda collection. Genetic Resources and Crop Evolution, 46 (6): 611-618.

Jose, F.; C. Barros, M. D. Carvalho and G. Basch (2004). Response Safflower to sowing date and plant density under Mediterranean condition. Europe Agronomy Journal, 21: 347-356.

Kaya, M. D.; A., Pek and A., Ozdemir (2003). Effect of different soil salinity levels on germination and seedling growth of Safflower (Carthamus tinctorius L.). Journal of Trend Agriculture Forest 27: 221-227.

Koutroubas, S. D.; D. K., Papakosta and A., Doitsinis (2009). Phenotypic variation in physiological determinants of yield in spring sown Safflower under Mediterranean conditions. Journal of Field Crops Research, 112: 199-204.

Li, D. and H. H., Mundel (1996). Safflower (Carthamus tinctorius L.) Promoting The Conservation And Use Of Underutilized And Neglected Crops.7. Institute Of 
Plant Genetics And Crop Plant Research, Gatersleben. International Plant Genetic Resources Institute, Rome, 83 pp.

Moghanlou, A. N.; H. K. A., Hossein Mostafaei, H. S.; T., Ghanifathi and R. G., Asl (2011). Survey Sowing Date and Density Different, on Seed and Oil Yield Two Cultivar Safflower (Carthamus tinctorius L.) in Region Ardabil. Journal of Science Research, 9 (2): 257-261.

Mundel, H. H.; R. J., Morrison; R. E., Blackshaw; T., Entz; B. T., Roth; R., Gaudiel and F., Kiehn (1994). Seeding date effects on yield, quality and maturity of Safflower. Canadian Journal of Plant Science, 74: 261-266.

Nimbkar, N. (2002). Safflower rediscovered. Times Agric. J. 2: 32-36.

Ozel, A.; T. Demirbilek; M. A., Gur and O., Copur (2004). Effects of different sowing date and intrarow spacing on yield and some agronomic traits of Safflower under Harran plain's arid conditions. Turkish Journal of Agriculture and Forestry, 28: 413-419.

Page, A. L.; R. H., Miller and D. R., Kenney (1982). Methods Of Soil Analysis. Part (2) Agronomy Number 9 Madison. USA.

Patel, B. M.; S. G., Sadaria; V. D., Khanpara; B. B., Kaneria and R. K., Mathukia (1997). Performance of Safflower varieties under different sowing dates. Gujarat Agricultural University Research Journal, 22: 133-135.

Pujari, B.; A., Kaht and B. S., Goudreddy (1993). Response of Safflower to different dates of planting and population. Haryana Journal of Agronomy, 9: 23-26.

Rao, V. P.; D. R., Reddy; B. B., Reddy and L. J., Rao (1990). Performance of Safflower genotypes at varying plant densities. Journal of Research. APAU, 18: 180-182.

Samarthia, T. T. and D. K., Muldoon (1997). Effect of irrigation schedules and row spacing on the yield of Safflower (Carthamus tinctorius L.). Journal of Oilseeds Research, 12: 307-308.

Snedecor, G. W. and W. G., Cochran (1982). Statistical Methods Applied To Experiments In Agriculture And Biology: 54-68. $7^{\text {th }}$ Ed. Seventh Reprinting. The Iowa State Univ. Press, Ames. Iowa, USA.

Stoffel, W.; F., Chu and E. H. J., Ahrens (1995). Analysis of long chain fatty acids by Gas Liquid chromatography, micro-method for preparation of methyl esters. Analytical Chemical, 31: $307-308$.

Tomar, S. S. (1995). Effect of soil hydrothermal regimes on the performance of safflower planted on different dates. Journal of Agronomy and Crop Science, 175: 141-152.

Zel, A.; T., Demurbulek; M., Atilla and G. R. O., Opur (2004). Effects of Different Sowing Date and Intrarow Spacing on Yield and Some Agronomic Traits of Safflower (Carthamus tinctorius L.) Under Harran Plainos Arid Conditions. Turkish Journal of Agriculture and Forestry, 28: 413-419.

Zimmerman, L. H. (1972). Effect of temperature and humidity stress during flowering on Safflower (Carthamus tinctorius L.). Journal of Crop Science, 12: 637-640. 